\title{
Oxygen and Carbon isotopes and carbonate chemistry in phoscorites from the Catalão I complex - implications for phosphate-iron-oxide magmas
}

\author{
P. F. O. Cordeiro' ${ }^{1}$ J. A. Brod ${ }^{1}$ and R. V. Santos ${ }^{1}$ \\ ${ }^{1}$ Institute of Geosciences, University of Brasília, Brazil
}

Phoscorites are rocks dominated by apatite, magnetite and a magnesian silicate. In the Late-Cretaceous Alto Paranaíba Igneous Province (APIP), central Brazil, such rocks are particularly abundant in the carbonatite complexes of Catalão and Araxá (Brod et al. 2004).

The Catalão I complex intrudes Late-Proterozoic schists and quartzites of the Brasília Belt, which are fenitized and deformed into a dome structure. Phoscorites and associated dolomite carbonatites (DC) occur as small, steeply dipping intrusions and stockworks of thin dikes with sharp contacts. DC also occur as globules and irregular pockets in phoscorite. Both are hosted in metassomatic phlogopitite, the dominant rock-type in the complex.

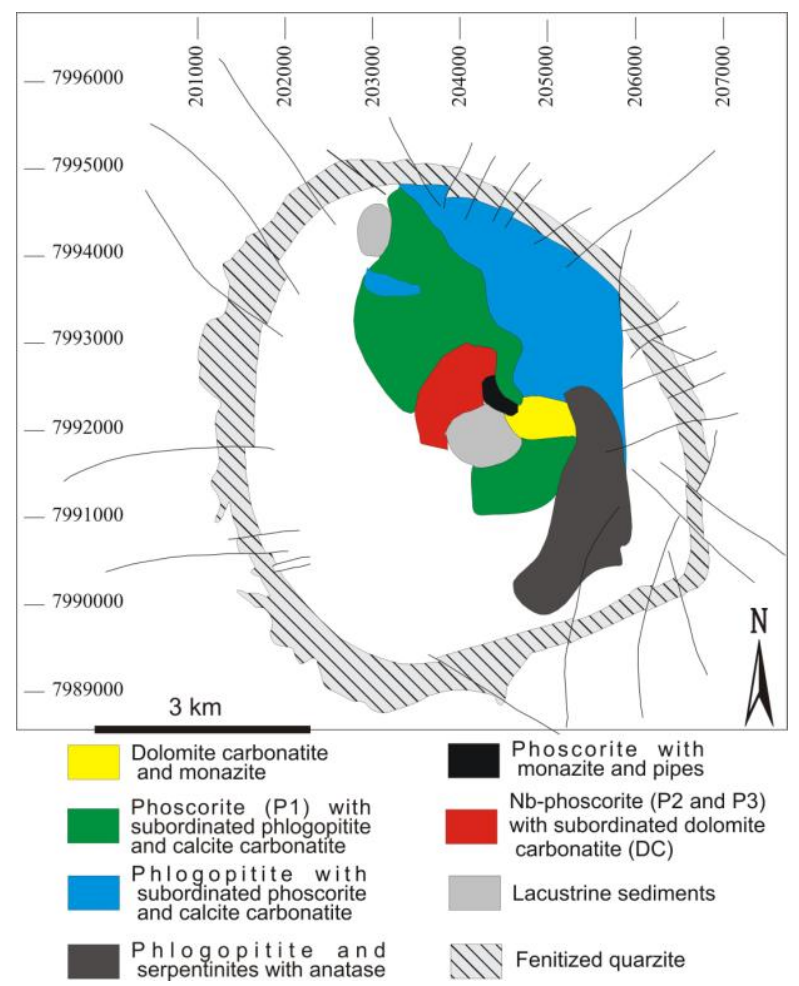

Fig. 1 Catalão I complex (after Ribeiro, 2008)

\section{Petrography}

Phoscorite-series rocks from Catalão I are divided into early-stage olivine phoscorite (P1), and late-stage phlogopite phoscorite (P2 and P3).

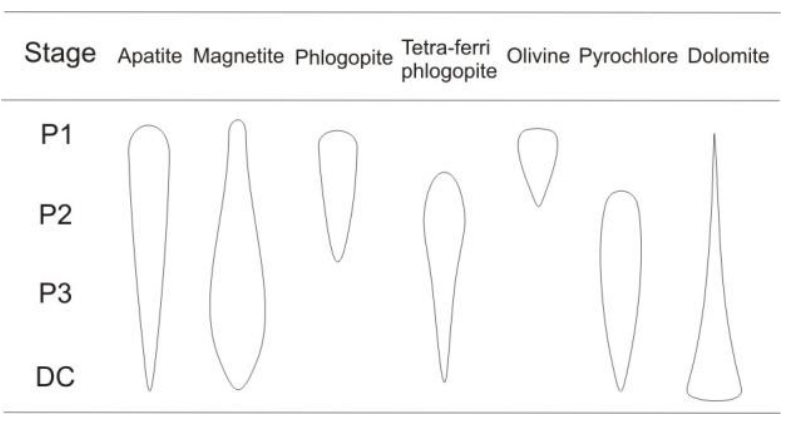

Fig. 2 Modal composition of studied rocks.

Olivine phoscorite, P1, occurs as dikes and small intrusions with coarse- to medium-grained olivine and apatite and medium- to fine-grained magnetite and phlogopite. They are metasomatised to a variable degree, with transformation of olivine into phlogopite.

Phlogopite phoscorites, P2 and P3 are the equivalent of nelsonites in the Yiegorov (1993) classification. They form stockworks of medium- to fine-grained dikes, typically lack olivine and are composed mainly of tetra-ferriphlogopite, apatite, magnetite, and dolomite, with accessory barite and norsethite. Pyrochlore hosted in these rocks forms the primary $\mathrm{Nb}$ mineralization of Catalão I. Carbonates occur both in the groundmass and as irregularly shaped pockets within the phoscorite. The carbonate pockets usually contain inward-growing crystals of ilmenite, apatite, and tetra-ferriphlogopite forming a radiate texture.

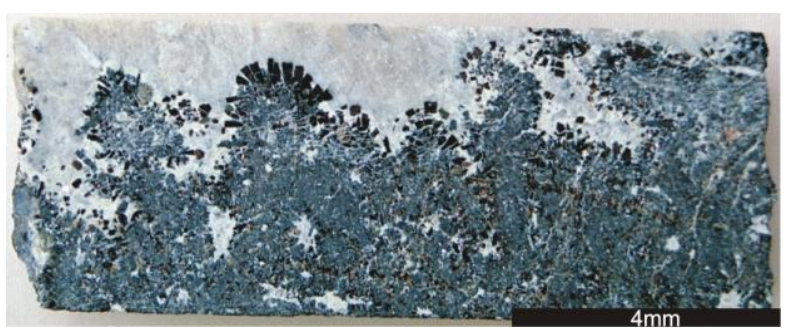

Fig. 3 Phlogopite-phoscorite (P3) with DC pocket. 
Dolomite carbonatite dikes with the same composition as the carbonate globules are interpreted as melts extracted from the phoscorites.

Previous studies argued that phoscorites evolve by assimilation-fractional crystallization and addressed whether phoscorite series derived from a carbonatitesilicate parental magma or was generated by an independent primary magma (Krasnova et al. 2004), concluding that they represent mantle-derived magmas occurring in close spatial and temporal association with carbonatites.

\section{Dolomite chemistry}

Dolomite crystals are coarse- to medium-grained and may show a "clear" or "cloudy" aspect in thin section. In hand specimens, cloudy dolomites are white and brittle, whereas clear carbonates are gray and fresh. Cloudy dolomite has less than 1.4 wt.\% $\mathrm{SrO}$ and clear crystals range from 1.78 to 4.76 wt. $\%$ SrO.

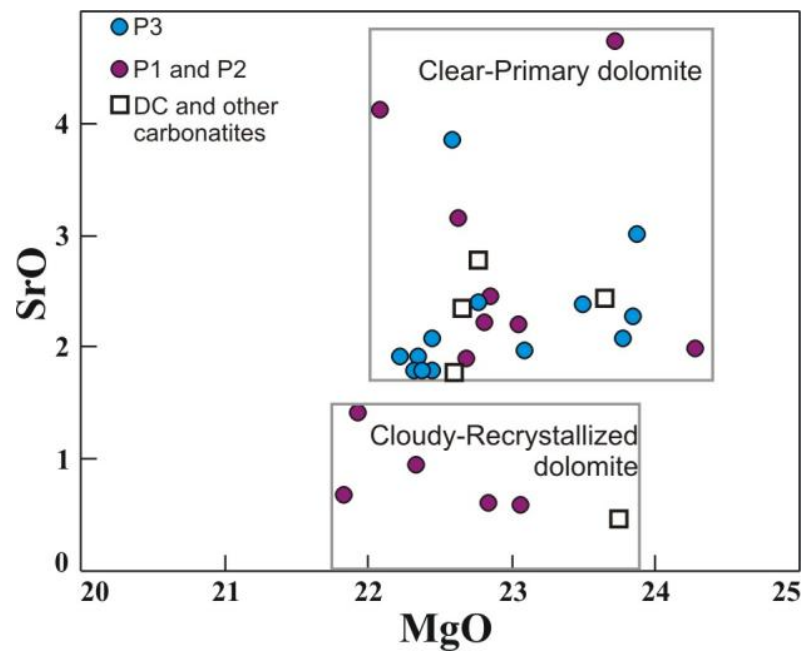

Fig. 4 Dolomite compositions from Catalão I phoscorites.

Cloudy dolomites result from variable degrees of weathering and metassomatism. Their cloudy aspect is due to exsolution of strontianite and opaques during subsolidus recrystallization. Clear crystals represent preserved primary carbonates and have high $\mathrm{SrO}$ content.

\section{Carbon and Oxygen Isotopes}

The isotopic composition and factors that control it in carbonatites are well known (Deines, 1989). Primary carbonatites have $\delta^{13} \mathrm{C}_{\mathrm{PDB}}$ between $-4 \%$ and $-8 \%$, and $\delta^{18} \mathrm{O}_{\text {SMOw }}$ between $+6 \%$ and $10 \%$ (Taylor et al., 1967). The isotopic composition may be affected by processes such as degassing and AFC, and by post-magmatic alteration. Country-rock assimilation is often invoked to explain anomalous values of $\mathrm{C}$ and $\mathrm{O}$ isotopes (e.g. Santos and Clayton 1995). Fluid-rock interaction may also affect the isotopic values at high and low temperature (Deines 1989; Santos and Clayton 1995).
In contrast, isotopic data on the carbonatite-phoscorite association are scarce and restricted to a few complexes. Available data include C-O isotope studies of Sokli, Turiy Mys, Vuoriyarvi, and Kovdor complexes from the Kola Alkaline Province (Demeny et al., 2004). In the case of Sokli, the authors argued that the data support the liquid immiscibility model between carbonatite and phoscorite liquids proposed by Lapin (1982). Carbon and oxygen isotopes from Sokli fit well along the carbonatite trend, suggesting that not only phoscorites and carbonatites have the same source, but evolved along similar paths. On the other hand, Dunworth and Bell (2001) concluded on the basis of isotopic data. For Demeny et al. (2004) there is no uniform stable isotope model for the phoscoritecarbonatite association.

Isotopic composition of the Catalão I phoscorites and associated dolomite carbonatite pockets and dikes vary by ca. $15 \%$ in $\delta^{18} \mathrm{O}_{\mathrm{SMOW}}$ and ca. $4 \%$ in $\delta^{13} \mathrm{C}_{\mathrm{PDB}}$.

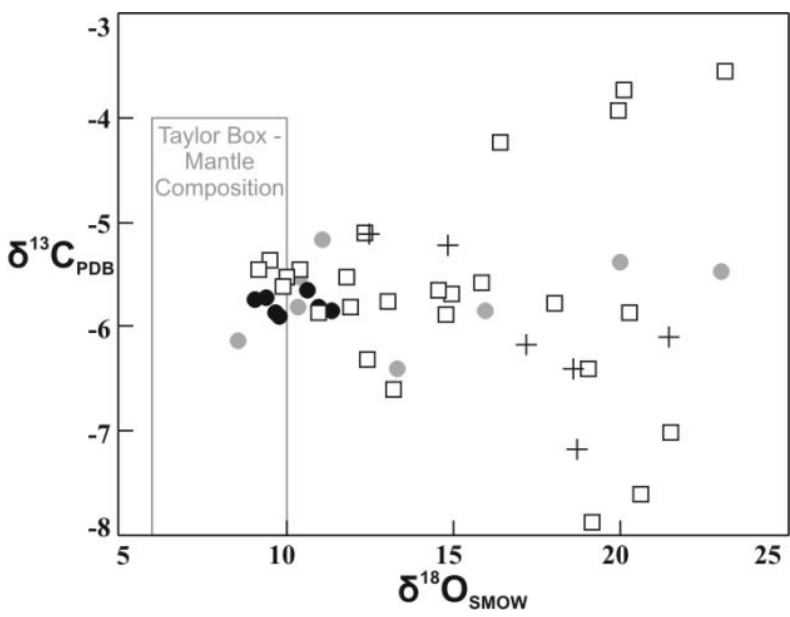

Fig. 5 Isotopic data for Catalão I carbonates. Black = dolomite-carbonatite (DC) pockets in P3; gray = DC pockets in $\mathrm{P} 2$; squares = carbonatites; crosses $=$ veins

Group 1 in Fig. 6 is composed of carbonates with carbonatite-like carbon isotopic values, and oxygen values slightly higher than those expected for mantlederived rocks. It is possible that the high oxygen isotope values in this group are related to magmatic process such as liquid immiscibility or crystal fractionation. Under these circumstances the oxygen isotopic composition of the carbonate would be related to the isotopic fractionation between carbonates and other minerals, as well as to the temperature and the isotopic composition of the initial melt.

Group 2 is represented by metassomatic carbonates that occur in veinlets and are associated with altered minerals and fractures.

Group 3 has higher $\delta^{18} \mathrm{O}$ and $\delta^{13} \mathrm{C}$ values than expected for mantle derived carbonates. A shift toward higher values in both $\delta^{18} \mathrm{O}$ and $\delta^{13} \mathrm{C}$ could be explained by assimilation of crustal components or interaction with meteoric fluids. However, given the location of these 
rocks near the center of the complex, little country-rock assimilation would be expected, at least at the emplacement level.

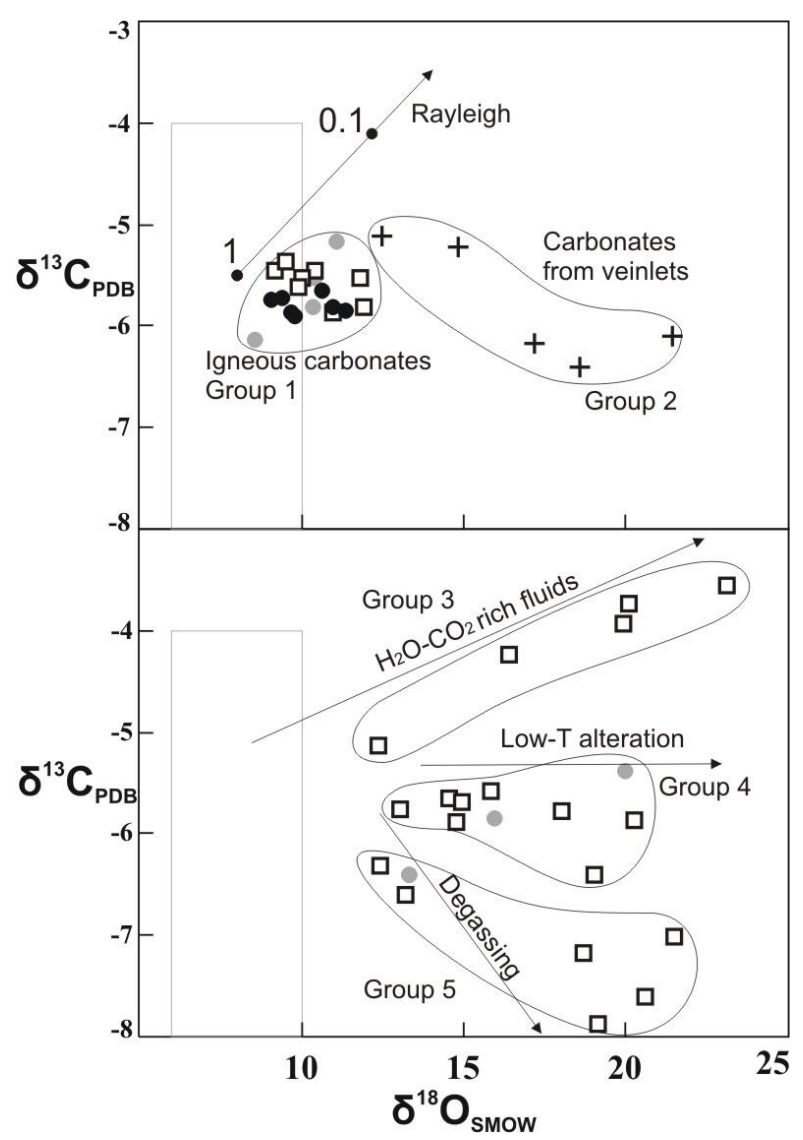

Fig. 6 Oxygen and carbon isotopes of different types of carbonate from Catalão I. Samples were grouped according the isotopic behavior.

Group 4 presents high $\delta^{18} \mathrm{O}$ values, but carbonatite-like $\delta^{13} \mathrm{C}$ values. These rocks probably interacted with water-rich fluids, thus selectively affecting the oxygen isotopes.

Group 5 samples have high oxygen isotopic values but carbon isotopic values lower than that expected for primary carbonatites. A possible alternative to explain this combined signature in carbonatite environment is degassing of $\mathrm{CO}_{2}$ from the carbonate melt. This may occur during decompression and may be accompanied by crystallization/precipitation of calcite. A similar process was discussed by Zheng (1990), who argued that a degassing processes where calcite is in equilibrium with $\mathrm{HCO}_{3}^{-}$, may lead to formation of carbonate with progressively negative carbon isotope values. We argue this process may also occur when carbonatite magma is submitted to decompression, thus explaining the negative trend observed in Group 5 samples. Further investigation of this trend is currently in progress.

\section{Acknowledgements}

This work was suported by Brazilian agencies CNPq and CAPES, and by the University of Brasília.

\section{References}

Brod, J.A., Ribeiro, C.C., Gaspar, J.C., JunqueiraBrod, T.C., Barbosa, E.S.R., Riffel, B.F., Silva, J.F., Chaban, N., Ferrari, A.J.D., 2004. Excursion guide: Geologia e Mineralizações dos Complexos Alcalino-Carbonatíticos da Província Ígnea do Alto Paranaíba. Soc Bras Geo.

Deines, P., 1989. Stable isotope variations in carbonatites. In: Bell K (ed) Carbonatites: Genesis and Evolution, Unwin Hyman, London, pp 301-359.

Demény, A., Sitnikova, M.A., Karchevsky, P.I., 2004. Stable $\mathrm{C}$ and $\mathrm{O}$ isotope compositions of carbonatite complexes of the Kola Alkaline Province: phoscoritecarbonatite relationships and source compositions. In: Wall F and Zaitsev AN (eds) Phoscorites and Carbonatites from Mantle to Mine: the Key Example of the Kola Alkaline Province, 1st ed. Mineralogical Society Series, London, pp 407-431.

Santos, R.V., \& Clayton, R.N., 1995. Variations of oxygen and carbon isotopes in carbonatites: a study of Brazilian alkaline complexes. Geochimica et Cosmchimica Acta 59:1339-1352.

Ribeiro, C.C. 2008. Geologia, geometalurgia, controles e gênese dos depósitos de fósforo, terras raras e titânio do Complexo Carbonatítico Catalão I, GO. University of Brasilia, $\mathrm{Ph}$. D. Thesis (in portuguese)

Gibson, S.A., Thompson, R.N., Leonardos, O.H., Dickin, A.P., Mitchell, J.G., 1995. The Late Cretaceous impact of the Trindade mantle plume - evidence from largevolume, mafic, potassic magmatism in SE Brazil. Journal of Petrology. 36:189-229.

Krasnova, N.I., Petrov, T.G., Balaganskaya, E.G., Garcia, D., Moutte, D., Zaitsev, A.N., Wall, F., 2004. Introduction to phoscorites: occurrence, composition, nomenclature and petrogenesis. In: Wall $\mathrm{F}$ and Zaitsev AN (eds) Phoscorites and Carbonatites from Mantle to Mine: the Key Example of the Kola Alkaline Province, 1st ed. Mineralogical Society Series, London, pp 45-79.

Zheng, Y.F., 1990. Carbon-oxygen isotopic covariation in hydrothermal calcite during degassing of $\mathrm{CO} 2$.

Dunworth, E.A., Bell, K., 2001. The Turiy Massif, Kola Peninsula. Russia: Isotopic and geochemical evidence for multi-source evolution. Journal of Petrology 42:377-405.

Lapin, A.V., 1982. Carbonatite differentiation processes. International Geology Review. 24:1079-1090.

Taylor, H.P., Frechen, J., Degens, E.T., 1967. Oxygen and carbon isotope studies of carbonatites from the Laacher See District, West Germany and the Alno District, Sweden. Geochimica et Cosmchimica Acta 31: 407-430.

Yiegorov, L.S. 1993. Phoscorites of the MaymechaKotuy ijolite-carbonatite association. International Geological Reviews, 35, 346-358.

Zheng, Y.F., 1990. Carbon-Oxygen Isotopic Covariation in Hydrothermal Calcite During Degassing of CO2 - a Quantitative-Evaluation and Application to the Kushikino Gold Mining Area in Japan. Mineralium Deposita. 25(4): p. 246-250. 